\title{
Jan Patočka and French Phenomenology
}

Karel Novotný

Journal of French and Francophone Philosophy - Revue de la philosophie française et de langue française, Vol XXIX, No 1-2 (2021) pp 1-21

\author{
Vol XXIX, No 1-2 (2021) \\ ISSN 1936-6280 (print) \\ ISSN 2155-1162 (online) \\ DOI $10.5195 /$ jffp. 2021.989 \\ www.jffp.org
}

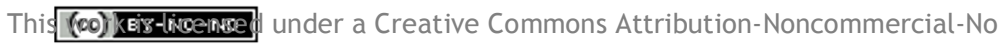
Derivative Works 3.0 United States License.

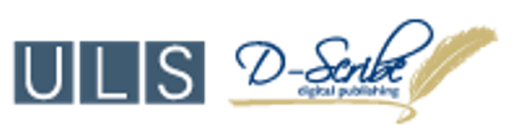

This journal is operated by the University Library System of the University of Pittsburgh as part of its D-Scribe Digital Publishing Program, and is co-sponsored by the University of Pittsburgh Press 


\title{
Jan Patočka and French Phenomenology
}

\author{
Karel Novotný \\ Charles University
}

In his phenomenological works-works that are thematically centered above all around the question of the natural world-Jan Patočka increasingly referred to movement and lived/physical corporeality [Leib-Körperlichkeit], precisely because he conceived the concept of the world in terms of the correlation of life with its milieu.1 Patočka developed his phenomenology, in conjunction with Edmund Husserl's late phenomenology of the lifeworld, ${ }^{2}$ by taking lived corporeality as his starting point and guiding motif in a way that is parallel to Merleau-Ponty's work. Patočka himself saw that this accent on corporeality indicated a kinship with French phenomenology. ${ }^{3}$ In our opinion, such an emphasis was also one of the reasons why he kept his distance from Eugen Fink's philosophical cosmology. And it is Patočka's reference to this cosmological project that has had, and keeps on having, an important impact on the recent reception of his work in France.

Thus not only does Patočka's understanding of the lifeworld display the influence of French thinkers, but his work has become important for the development of phenomenological philosophy in France, particularly in one respect to which we shall limit ourself here: by virtue of his critical engagement with Eugen Fink, Patočka has become one source of the turn toward philosophical cosmology in French phenomenology, above all in the works of Renaud Barbaras, as well as in the work of authors he has influenced, like Pierre Rodrigo, and of some of their former PhD students working on Patočka. ${ }^{4}$ This is, of course, merely one moment in the abundant development of phenomenology in France, but it is an important moment that greatly enhanced the reception of Patočka's work in general, and not only in France itself. 


\section{The World and Movement}

There is one passage that is cited especially often in readings of Patočka that are looking for a cosmology in his work. It accordingly seems important to take this passage as a point of departure in our presentation as well. This is a matter of a short reference-only a few paragraphs long-to Eugen Fink's philosophical position, appearing in the second part of the Afterword to the new edition of the habilitation The Natural World as a Philosophical Problem. At the beginning of this text passage on Fink, which closes Patočka's introductory part before he comes to a presentation of his own new position (namely, the theory of the three movements of human existence), ${ }^{5}$ he notes that with "a yet more unrepentantly speculative bent" than Heidegger displays with his notion of Ereignis, ${ }^{6}$ Fink has held it possible "to receive into an ontological context the world in the strong sense of the word, the independently existing world." At the same time, he wonders whether this would effectively reestablish the "age-old" notion of physis as arche ruling in each individual. ${ }^{7}$ In a series of similar questions that already serve to indicate his distance from Fink, Patočka sketches the position of the latter's philosophical cosmology in order to contrast it with Heidegger's account of the history of being. It is only at the end of this passage that Patočka speaks of his own account, positioning it between Fink's cosmology and Heidegger's thinking of being as two different fundamental positions, writing: "The movement would be here the middle term between the two fundamental ways in which being uncovers existents and thereby shows itself to be their origin and ruling principle, arché." 8

What, then, are the two ways from which Patočka's presentation departs here, and how is movement related to them? Patočka addresses the contrast in the following way: what for us is the being of the existent-namely, the ground upon which we stand and upon which we ourselves are first the existent whose being consists in understanding (Heidegger)-is for the things time-space as the prior holistic, non-individuated framework of all individuation (Fink). Following this comes the reference mentioned on the way Fink characterizes this cosmic framework (the entire tenth section of the afterword preceding these remarks was devoted to Heidegger). This framework itself would not be an existent, but would merely be thematizable in terms of the relationships things enter into within this framework. The manifestation of things that makes this possible in the first place is not a manifestation for the subject, but a manifestation as arising or coming into being, as a "step into singularity." It would be a manifestation to which the singularized things themselves are "inwardly indifferent" — a manifestation that is not revealing itself, but is submerged in the dark night of primal existents and primal being. So much for the way Patočka introduces Fink.

Even if Patočka was undoubtedly inspired to a considerable extent by both accounts in formulating his own project, he does not subscribe to either 
of them, as one can see in the publications appearing immediately after he wrote the afterword. ${ }^{9}$ We cannot find there any tendency of their author "to receive into an ontological context the world in the strong sense of the word, the independently existing world," or correspondingly, to take up the notion of a contrast between appearing as appearing-to a subject with appearing as manifestation-of the world. ${ }^{10}$ His distance from these notions of Fink's is linguistically expressed in the conditional mood in the concluding paragraphs, where he reports on both accounts, cosmology and ontologydoing so, as already mentioned, in order to go on to present his own position. Here is the passage:

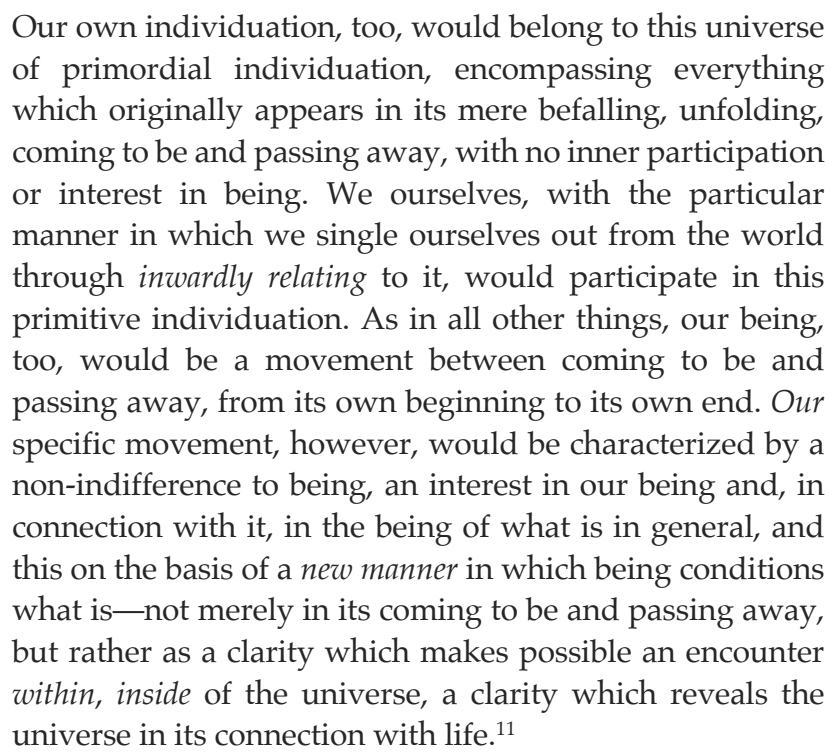

Neither the beginning of this passage on Fink's idea of individuation nor its final sentence on the "clarity which reveals" expresses insights that Patočka would reject. Yet neither the former nor the latter expresses what Patočka himself wants to say in critical connection with these positions. With his clear emphasis on lived/physical bodily life, he differs from Heidegger; at the same time, when it is a matter of grounding the individuation of beings in the understanding of their being, he seems to join Heidegger on this point, as opposed to cosmology. ${ }^{12}$ And it is the final word of the passage cited above"life" - that first provides the key to Patočka's own account of movement. The lived/physical corporeality of life, which expresses the primal fact of pluralization into "separate life-centers" and the particular modes of individuation in each case, does not just mean that as a lived/physical body, the body is a vehicle for participating in the universal "movement from arising to passing away" to which all things are subject-hence a movement to which we too belong; ${ }^{13}$ the lived/physical body simultaneously signifies a divergence from such a movement of the world, a difference with regard to 
it-and it is precisely this difference that is at stake when we speak of a difference from cosmologism in Patočka's work.

What Patočka is trying to do in this afterword is thus to take up the problematic of the natural world in a new way and to clarify his current position with regard to an old theme. ${ }^{14}$ Just as before, his interest still lies in clarifying the connection between world and life that he was speaking of in the passage cited above, even in the context of summarizing other positions. He will therefore be engaged with the notion of movement as a middle member, a means, a mediation, or a medium of the correlation of world and life. Here he is not dismissing the philosophical achievements of Husserl, Heidegger, Fink, or other thinkers; instead, the contribution they can make to the problem in question must be sought in the connection between their contributions and the considerations that Patočka himself now wants to bring to light.

Thus at the beginning of the third part of the afterword, he turns to the natural world, "searching for life in its originarity." ${ }^{15}$ Here he senses himself linked with the original aim of Husserl's phenomenology, while also drawing upon Heidegger insofar as the latter "radicalizes the phenomenology of intentionality toward a phenomenology of life as existence" as well as taking advantage of Fink, defending "Fink's idea of the ontological analysis of life as being necessarily, in each and every moment, an analysis of the world with its fundamental moments of time, space, and motion." ${ }^{16}$ For Patockka, then, it is a matter of broadening the ontology of life into an ontology of the world, against the background of understanding life as movement. Starting from life as movement-indeed, "human life as dynamis" — the concepts of space, time, and movement are to return to "their original ontological import,"17 so that it is the world in its pregivenness that is to be clarified in terms of life as movement, and not the other way around.

Here, giving the Aristotelian concept of movement a more universal scope plays a large role ${ }^{18}$-obviously, something that is likewise inspired by Fink. ${ }^{19}$ Patočka developed this theme in his historical treatise on Aristotle: His Predecessors and Successors, and was already considering a systematic application of this more universal notion of movement at that time. To be sure, passages testifying to this are rare, but the most important (though not the only) passage is found in Patočka's correspondence. ${ }^{20}$ Once again, this might give the impression that like Fink, he was moving toward a philosophical cosmology. But Patočka did not take such a step at any time. Perhaps his philosophy can be criticized for the lack of any systematic synthesis of its many motifs, but it cannot be faulted on the grounds that his attempt at cosmology was a failure. ${ }^{21}$ As we have already noted, not only did he never develop such an attempt, but he never attempted such a task in the first place. 


\section{Renaud Barbaras's Recent Critique of Patočka}

Renaud Barbaras has recently summarized his cosmological reading of Patočka ${ }^{22}$ in two essays, one on the "Ambiguity of the World" and the other on the "Repression of Life," ${ }^{23}$ where he contrasts his own thesis of the preeminence of the "physical" movement of the world with Patočka's interpretation of movement in terms of the primacy of our "spiritual" understanding of being. According to Barbaras, what is lacking in Patočka's interpretation of movement is the truly corporeal dimension of our belonging to the world, since even life is repressed by the spirit: both belonging-to-theworld and life itself are ultimately lost in favor of the spiritual movement of the understanding of being. In contrast to this, Barbaras emphasizes Patočka's references to Fink's cosmology in order to take them up for further development within his own project. Barbaras's approach is based above all on the following short fragment from Patočka:

Appearing as beginning from the obscure ground; that here there is a movement of appearing, a primal movement, can be read by analogy from secondary appearing, namely, from the appearing of the appearance that presupposes the coming into being of centers, of centrality: here the movement of transcendence creates a "world of its own," a surrounding world [. . .]. Likewise, there must be something like movement through which the heart of the world creates its contingent contents, whose sediment is space-time-quality as a whole. ${ }^{24}$

This passage, where Patočka is referring to Fink's account-and the last sentence in particular-has become the occasion not only for an extremely influential interpretation of the phenomenology of Jan Patočka himself, but for Barbaras's own phenomenological cosmology.

However, as we have indicated, the context can also be read in a different way, not as a failed attempt at a philosophical cosmology that remains stuck in the transcendentalism of a fundamental ontology based on the understanding of being (and thereby in dualism), but rather as a critical dissociation from Fink's cosmologism, one that likewise wants to distance itself from Heidegger's primacy of the understanding of being-and indeed, wants to do so precisely by accenting the lived/physical corporeality of existence, something that Patočka expresses unmistakably and repeatedly.

As proof of this, we can already cite a passage from the manuscript of a 1968 lecture according to which the first movement of existence is "a movement that does not originally refer to the mode of being," i.e., it proceeds instinctively, spontaneously, "in passivity and in accord with the world presenting itself, responding to the world's incitement with the movement 
that this elicits." 25 Thus here movement is not mediated by moods as forms of understanding of being, as Barbaras claims. ${ }^{26}$ Instead, sensuous life is set into motion from the outside, by something foreign, other than itself. This is certainly no denial of the cosmos and its effect on life-on the contrary. And yet the movement of life cannot be derived from such an effect of the cosmos, or of its movement, as a modality of it. What we are offering here is an alternative way of reading Patočka's texts in critical continuity with Husserl's transcendental-genetic account. For Barbaras, in its belonging-to-the-cosmos, lived/physical corporeality is reduced to and exhausted in the movement of the cosmos itself ${ }^{27}$ - a movement equivalent to life, a movement in which everything worldly, including human life, participates. In contrast, for Patočka, what such lived/physical corporeality points to is a plurality of lifecenters, all of whom form, from their own inner and in reciprocal contact with other life-centers, the medium of external expression-the world. This dynamic cannot be interpreted as a participation in the movement of the cosmos itself or as an individuation of worldly beings from this movement. Such an interpretation can be found neither in the research manuscripts nor in Patočka's published writings-it is only present where he is reporting on Fink's account. For me, this is a clear indication that Patočka himself was not attempting any cosmological turn in Fink's sense, although he really admired it.

Even when Patočka mentions philosophical cosmology (as he does, for example, in a letter to Irena Krońska we shall cite in the next paragraph), his own contribution is consistent with the project of a phenomenology of the world as a whole based on the experience of this world-whole, exemplified in the asubjective transcendentalism of the world-form. ${ }^{28}$ Even the accounts that take movement as a starting point, such as the third part of the afterword, clearly do not yield a cosmology in Fink's sense, but a type of transcendentalphenomenological philosophy of life: it is not the cosmos, but "human life as dynamis" that restores to the concepts of space and time-and of movement as well- "their original ontological import." ${ }^{29}$ And still, one seems to be able penetrate into "the realm of archai" by this route just as well as via Fink's philosophical cosmology.

Here is the passage from the aforementioned letter to Irena Krońska where Patočka uses these expressions:

I've certainly wanted to rework my ideas on the natural world and human existence in light of new considerations - but I strongly doubt that I can still manage to do this. My new points of view are that the natural world is not a problem to be treated separately-one must first rediscover the world (simply as the world itself), and then use ontological considerations to base the human world, both natural and constructed, on it. This might seem to revive a metaphysical concept, but that would be to misunderstand 
me, because it's a matter of a phenomenology of the world (the ontology in question is a phenomenological ontology, not a metaphysical one), and my idea is that a phenomenology of the cosmological totality is a possible undertaking. This implies an entirely different methodological conception than the Husserlian "reduction," a conception supported instead by considerations of modality in the manner of Fink, which allow me to establish the character of the world as irreducible [indépassable], considerations centered around the problem of the "barrier of language"-i.e., intraworldly expression applied to the totality; then a new theory of perception that dispenses with the traditional doctrine (above all, that of Kantianism) that one cannot experience the world as a totality. ${ }^{30}$ It would also be necessary to work out the fundamental distinction between a philosophical cosmology (aiming at the "essential" core of the world, beyond the opposition of fact and law, of the contingent and the necessary, penetrating into the core that totalizes and "governs" the world, the domain of archai) and a scientific cosmology tackling the secondary, contingent, factual contents of the world, a cosmology of which the sciences are parts or moments. ${ }^{31}$

Renaud Barbaras and Pierre Rodrigo are right to point out, and even to insist, that when in certain passages Patočka gives the Aristotelian concept of movement a more universal scope, a possible bridge to cosmology is suggested, a bridge that Fink has actually built. But we would certainly add that this stands in contrast to Patočka, who for his part remains on this side of such a bridge, working on a phenomenology of the world.

\section{Pierre Rodrigo and His Accent on Symphysis}

In his numerous contributions to the interpretation of Patočka's philosophy, Pierre Rodrigo too has relied on the influence of the Aristotelian theory of movement; for him as well, the interpretation and radicalization of this theory is a model for Patočka's turn away from Husserl and Heidegger and toward a new theory of appearing in which the latter is neither reduced to a transcendental subject nor attributed to the history of being. Instead of remaining with appearing as such, which phenomenologists would typically-and ideally-do, Rodrigo writes of the necessity of postphenomenology posing the most difficult question, i.e., that of the logic of the way in which manifestation and phenomenalization are geared in with one another-what links and differentiates the way in which the beings are individuated and manifested of their own accord (the way in which they 
arise) and the way in which the beings are perceived by living beings, are phenomenalized. The initial step toward this task is already decisive: namely, how is manifestation to be distinguished from phenomenalization in the first place. Fink first paved the way for this step with the conceptual pair, appearing-of [Vorschein] and appearing-to [Anschein]; ${ }^{32}$ in this way he identified clear limits of phenomenology, which must accordingly give way in favor of a philosophical cosmology. For him, here cosmos must be truly distinguished from the modes of appearance of everything encountered in the world: the cosmos does not genuinely manifest itself as itself in these innerworldly appearances.

To be sure, neither Barbaras nor Rodrigo are following Fink so far as to break with phenomenology, a break that Patočka and Merleau-Ponty did not even intend. Nevertheless, Merleau-Ponty and Patočka provided some inspiration for Barbaras to go beyond phenomenology and ontology toward a cosmological-metaphysical monism. Rodrigo seems to be inspired by the same move, developing arguments of his own-arguments for a postphenomenology that does call for a new metaphysics, yet without tending toward the monism mentioned. Rodrigo attempts to think through the concept of symphysis, a concept that Patočka once used, ${ }^{33}$ in order to formulate the most difficult question, that of the gearing-in of manifestation and phenomenalization. Here let us cite one formulation in which Rodrigo is following Barbaras:

"The question that is certainly the most difficult is precisely
to know if the movement that is ours-the movement from
which the appearance properly so called proceeds [i.e.,
phenomenalization] _can truly be produced from the
movement of manifestation. Can our phenomenalizing life, in
its difference, be thought from the movement of the world,
is its singularity rooted in a possibility of this movement?" 34
The entire post-phenomenological project does, of course,
only make sense if the response to this question is
positive.

Thus, while Fink unequivocally breaks with phenomenology (both with Husserl and with Heidegger, at least with the latter's early hermeneutical project), post-phenomenology from Merleau-Ponty through Patocka to Barbaras and Rodrigo himself is seeking a new correlation between the selfmanifestation of the cosmos and the appearing of the phenomena of our lifeworld. And post-phenomenology attempts to decipher this correlation on the basis of the latter-of appearing itself. This project can find support in Patočka in that he wanted to establish, phenomenologically, the world as a whole, or appearing as such, as a structure. Post-phenomenology nevertheless goes beyond this in order to track down a genesis of this structure itself as well, and indeed, to trace it to a movement that brings all beings into being. 
Thus we read as follows in the introduction to Pierre Rodrigo's book, in a passage whose testimony we want to cite in extenso here:

This means that the analysis of the structure of manifestation-as the structure responsible for there being existents-of-the-world, if one can formulate it this way-must be geared in with [engrenée] the structure of the appearance of the phenomena, a structure that is independent of the beings. To put it more technically, the "primary manifestation" of the world and of the existents-of-theworld must be geared in with the "secondary manifestation" of the phenomena to "someone," to a sum that is neither a transcendental ego nor a Dasein. For Patočka, this gearing-in [engrenage] is called "movement" as a phenomenological and metaphysical concept: movement of finite subjective life, "proto-movement" of the world and ontological movement (which is the sense of being that Aristotle glimpsed). It is this multiform movement that the 1968 manuscript on "Phenomenology and Ontology of Movement" names symphysis, i.e.- - and as we shall see, this is a key point-a process of the growingtogether [devenir-ensemble], without a substrate, of all the existents that exist, but also a process of the growingtogether of being itself and everything appearing to an existent that is itself participating in this process-to an existent that is "in it," as Merleau-Ponty would have said here. Of course, not everything in this difficult theorizingwhich concerns what we have called a new correlation between phenomenon and being-is fully carried through to the end. ${ }^{36}$

This is a summary of a program (now related to the interpretation of Patočka's thought, to which we limit ourselves here) that simultaneously indicates an internal problem of that interpretation and points to a solution based on something borrowed from Fink, namely, from his distinction between appearing-of and appearing-to, which for Barbaras become primary and secondary manifestation.

I have already pointed out that Patočka had never accepted this distinction. And the place in Patočka that Rodrigo cites in the same passage we have just quoted from the Introduction to his most recent book-a place whose sense he follows in his own-belongs to the context of sketching an alternative to Fink's cosmologism. Patočka explicitly terms what he is aiming for a "transcendentalism of appearing as such." Here is the place Rodrigo cites, albeit without the initial sentence: 
We believe that-as primary - the problem of appearance is the natural consequence of a transformation of the Husserlian theory into a formal transcendentalism of appearing as such. If the epoche means nothing other than returning from the supposedly pregiven world (the worldconstruct and natural cognition) to the plane of appearances-i.e., to the appearance-characters that are nothing but characters of the understanding of being with respect to what is found in the being of the world, characters that are themselves no longer dependent on the occurrence of perceiving beings-then the primacy of appearing over being is obvious. One is no longer in danger-a danger tangible in Heidegger-of linking aletheia and pseudos, agathon and kakon, so tightly that there is the threat of a reversal of signs, that the penchant for doing this leads philosophical questions into a darkness with no way out. On the contrary, the primacy of appearing establishes the primacy of light; without negating darkness, the priority of the light is established..$^{37}$

Patočka's most extensive manuscript on this theme thus ends with the paragraph just cited, where we find a profession of "a-subjective" transcendental phenomenology in its very first phrase. ${ }^{38}$

I have cited both passages at length in order to indicate how Rodrigo's reading, with its emphasis on symphysis, is perhaps nearer to Merleau-Ponty as a thinker oriented to the correlation of phenomena and being than to the cosmologists Barbaras and Fink. To put it in a nutshell, what is attempted with the new "post-phenomenological" figure of symphysis as the correlation of being and appearing is an intertwining of appearing and being on the basis of the analysis and interpretation of the logic of appearing itself, instead of proceeding with the speculative constructions of physis or of a cosmos that must still be distinguished from the world of phenomena-which is, by the way, something that Rodrigo never claims. ${ }^{39}$ When he takes over Barbaras's difference between primary and secondary manifestation, it is not in order to use it as a means to subsume the secondary in the primary, thereby establishing a monism of the world in the strong sense of the word. To put it another way, for Rodrigo, Merleau-Ponty's "intertwining" is and remains an important insight.

In asubjective phenomenology, appearing is consistently detached both from the transcendental subject or Dasein and from what appears (which is thereby objectivated), so that appearing is lifted, as it were, into an autonomy of its own. In his transcendentalism, then, Patočka accordingly speaks of appearing as such as well as limiting himself in this project to the form or "structure" of this appearing, something that Rodrigo also mentions in his commentary on the first passage. The aforementioned internal problem of 
interpreting Patočka's philosophy then consists in describing how this "static" asubjective phenomenology, which concentrates on intuitively grasping a structure, is to be synthesized with the task of taking movement as a point of departure. And there is a letter testifying to the fact that this is not a matter of a problem external to Patočka's own project, for in the following passage of the letter in question, he himself characterizes his project in a way that also suggests its relevance for Rodrigo's question regarding the gearingin, engrenage, of appearing and being through movement:

Moreover, I want to place the lifeworld in the middle, between the concept of the universe and the ontological concept of the world, relating it not to the reflectively grasped subject, but to fundamental movements of human life, with which the "objectivation" of lifeworldly references in action and cognition would first be linked [. . .]. I think that the determination of the relationship between the lifeworld, as an ontic concept, and the ontological concept of the world has never been carefully undertaken. ${ }^{40}$

Yet while the inquiry here clearly proceeds from the movements of human life that are to replace the Cartesian construct of a reflectively grasped subject, for Barbaras and Rodrigo it is a question of thinking these movements too "from the movement of the world," as we have seen above. With Barbaras it is increasingly a matter of metaphysically establishing a monism. Nevertheless, even though Rodrigo has some affinity for this development, he pursues an emphasis of his own, and therefore offers the following questions and remarks concerning Barbaras's ontological project:

Perhaps the "co-originarity of Being and Life" [Barbaras 2013, 163] does not imply-if we remove the capital letters-some primordial level (or a level that is supposed to be primordial) of neutrality. Couldn't it be, in effect, something on the order of an ecstatic mode or a dynamic mode of being - one that would be termed "distance" or "desire" from the side of the living being and "depth" from the side of the world. ${ }^{41}$

We believe that this correlation-a correlation belonging to symphysisis a correlation of life and of depth inherent to what surrounds life and makes it possible. And this also seems to us to be the emphasis in Rodrigo when he is reporting on the most recent development in the work of Barbaras, work that is compelled by the monistic logic of the latter's thinking to reduce this duality too to the depth of the world:

There accordingly remains an essential step to be taken after this post-phenomenological trajectory in order to dismiss dualism more radically, thereby "saving" the correlation-or rather, saving the careful theoretical 
enterprise from betraying his monistic logic. This step is accomplished in the work entitled L'appartenance, where "[. . .] depth is, in other words, the originary mode of phenomenalization of the soil [sol], the inaugural presence of the ontological in the phenomenal." ${ }^{42}$ Determined in this way, the soil founds and dynamically maintains a continuity of belonging-to with the phenomenal appearing that is like its other side, its own "metaphysical explosion." $43-44$

A phenomenologist would ask: how is the depth of the world given, and how is the world itself given? Depth is certainly not given in itself, but only with reference to something, like to a nullpoint of orientations, hence to the lived/physical body of the living being-properly speaking, only to humans, who-as the classical response puts it-long for depth and distance. For a phenomenological metaphysics, this would be a matter of a primal fact. In contrast, a world in itself that is never manifested to anyone is thinkable, or as Patočka would probably say, perhaps merely thinkable. ${ }^{45}$ For Rodrigo, however, even in post-phenomenology and its metaphysics, it is explicitly a matter of thinking anew the correlation that still links such anonymous manifestion with the phenomena that we living beings experience. And for Rodrigo, Patočka has pointed this out with his concept of symphysis. The way in which Rodrigo makes use of the concept nevertheless goes far beyond the sparse hints in Patočka himself. For Rodrigo, once again, symphysis is a "process of the growing-together, without a substrate, of all the beings that exist, but also the growing-together of being itself and everything appearing to a being that is itself participating in this process." 46 It is a merit of this author to put with this term of symphysis an emphasis on a new possibility of thinking the intertwining of being and appearing.

\section{Generalizing the Movement}

Patočka has recourse to this notion of symphysis in a manuscript from the end of the 1960s, "On the Ontology and Metaphysics of Movement." This is not a matter of a text that has been completely worked out; instead, it consists for the most part of notes and excerpts. But what is important is that Patočka is obviously returning there to his idea of ontological movement from a certain distance. The initial notes of this document explicitly refer to passages in the Aristotle book where the idea of ontological movement originated, passages that are so thought-provoking-and not only within in the framework of the cosmological reading by Barbaras and his followersthat they open up a path of their own that we shall selectively pursue here.

Under the title "movement," these notes of Patočka point right at the start to a fundamental duality: "1) If movement along ontological lines has the 
particular aspect that in contradistinction to the concept of existents, it cannot be self-contained"-something toward which this concept tends via the notion of the determinations proper to the existent, making it an "independent substrate" — then "movement (even the most elementary physical movement) is only inwardly possible, as well as understandable and cognizable, when each determination is transcended in the direction toward the in-finite, toward the universe of existents. 2) Human experiencerelationship to entities, holding sway in the lived body and intervening by means of this in external reality, all of which [is] only possible through movement-movement-theory of perception, of willing, of human existence." $^{47}$

In this sketch we do not find any one-sided inclusion of subjective movement in the movement of all-encompassing physis, or in the world in the sense of a cosmos; instead, we find a particular type of intertwining of the two types of movement, a motif that one can already find in Patočka's early unpublished work, although not only there. ${ }^{48}$ Hence in the case of Patočka, we cannot find any attempt to derive all individual movements-both those of organic life as well as those of inorganic things-from a primal movement as its modalities. Instead, he speaks of their common denominator, of the general characteristic of these movements: here, movement means "the transition from non-being to being and vice versa," or "simultaneously: to become something, i.e., to go from something's non-being to beingsomething". ${ }^{49}$

The emphasis on a "something" signifies the inner-worldly characteristic of these movements, while the world itself is not a something and cannot become one. We find this idea of a common character schematically repeated as a summary at yet another place in the same manuscript:

There are two main forms of movement: a) objective movement $\alpha$ ) location-movement, as sheer change of location $\beta$ ) "process"[;] b) lived movement, movement of psychophysical beings[.] The synthesis of both: socialhistorical movement, objective movement resulting from the interplay of subjective movements[.] What underlies them both is the ontological nature of movementmovement as transition from non-being to being or vice versa[.] $]^{50}$

The thesis of an "ontological movement" as a common character of individuation both in living and lifeless existents is obviously a further step away from the idealistic theory of constitution and toward an "asubjective" phenomenology of the world as a whole. Nevertheless, the step from the idea of a common character of objective and lived movement to the thesis of the ontogenetic movement of the world in Barbaras and Rodrigo is too great a step, one we can find neither in Patočka's published writings nor in his 
working manuscripts and sketches. Instead, the world is to be interpreted not in terms of the cosmos, but in terms of life-we have already mentioned one passage. ${ }^{51}$ And for Patočka, life does not merely have an organic, lived/physical bodily dimension; moreover, when we read his later reflections on radicalizing the concept of movement, it is not merely a matter of the formal dimension of movement. There is also a transcendental dimension of life that may be connected with the latter motif, but doesn't coincide with it. ${ }^{52}$

\section{Conclusion: The First Movement and the Earth that Does Not Move}

In the 1970 afterword we have already referred to in this essay, Patočka speaks quite unequivocally of humans as belonging to a world in the strong sense of nature, and he does so on the basis of movement. Yet he is always talking about our movement, or about a movement of existents becoming in the world, never about a movement of the world itself-a movement that would first make this belonging-to-the-world possible. Of course, this is in no way a denial of such belonging. Even when Patočka links movement with the lived/physical body, directing his attention to this above all, what is important to him, particularly in relation to the so-called first movement of life, is to emphasize its cosmic dimension, and hence the belonging of human life to nature in the old sense of phusis.

Nevertheless, the corporeality of all motion keeps before our eyes the fact that, insofar as we move, take action, and in so acting understand at once ourselves and things, we are part of nature, phusis, the all-embracing world. When interested and occupied above all with human relations and social functions, living in and for work, organization, struggle and competition, we tend to forget this natural aspect and, at the same time, our relationship to the all-embracing phusis. The first of our fundamental, overall movements, the movement of anchoring or sinking roots, which grounds the other two, is, however, most suitable to remind us of this supremacy of phusis in the whole of our life. In fact, all our actions, including precisely work and struggle, take place solely on the basis of this instinctive-affective prime motion, which constitutes so to say the ostinato of life's polyphony. ${ }^{53}$

The confrontation of Patočka's philosophy with philosophical cosmology is thus thoroughly legitimate and productive, and its intensive reception in the last fifteen years owes much to this confrontation.

What links his own revisions of transcendental phenomenology together, and what comes into the foreground in the final decades of his work, is the insight that the medium of our encounter with individual items in the world is to be grasped as movement. As already mentioned, however, Patočka in no 
way speaks of a cosmological movement of the world itself-in, say, the sense of a primary manifestation-but always simultaneously speaks of two movements: the medium of the correlation is "our own movement within the framework of the world and the movement of everything that can occur and appear in the world." 54 The life of human beings is therefore to be characterized in general as "the movement of a world-beings," in the sense that it "never brings about anything specifically human without this being related-tacitly or explicitly-to the preceding whole." ${ }^{55}$ Yet how is this world-relation to be realized concretely?

In this connection Patočka speaks (not only in the essay cited here, but also in his other writings) first and foremost of the earth as the indispensable referent of every movement. The earth is "above all the firm foothold and foundation of any movement-ours as well as that of other things." 56

Although in its transcendental function, the earth is to be the primal factual support for the sense-constituting movement of life, the earth itself does not move: it makes a cosmic power of nature present, one that penetrates everything living and holds sway in all life as a result. Instead of being related to life as its object, as that which responds to its intentionality, the earth also underlies the human relation to the whole, albeit unthematically.

If it is movement on both sides of the correlation that makes this possible, and if this has a common denominator-namely, making an existent in general what it is, without any recourse to an already existing substrate-then this means that the beings become being in the world through reciprocal movement, through the intertwining of both movements. They are not first individuated in and through the movement of the cosmos in order to become the beings in the world-phenomenalized in relation to the life-centers, the incarnated subjectivities-only secondarily. On the contrary, Patočka repeatedly tells us that the life to be grasped as this movement is originally the life that would be human life as the movement whereby beings become without substrates already underlying this movement as what bears it. This lived, subjective bodily movement cannot be reduced to any other movement, and is even awarded a certain priority in its phenomenological accessibility. This obviously doesn't mean that this movement could happen autonomously, occurring of itself without being related to something that calls for it-and for its part, enables it-as an external realization of its possibilities. Neither of these two movements is possible prior to the other of them when it is a matter of a being becoming what it is: the so-called ontological or ontogenetic movement is possible exclusively within this reciprocity or correlation. This irreducibility of the movement of life to Fink's cosmic "play without a player," 57 as well as the phenomenological priority of the correlation of inner and outer in one's own lived/physical body as opposed to the cosmological difference, is spelled out in a December 1968 lecture Patočka gave in Freiburg at the invitation of Eugen Fink. ${ }^{58}$ 
Even when for Patočka as well, the world as a whole can be thought with-in Fink's terms - the play of appearing that yields time and space as the ultimate framework of the encounter between life and this externality, life nevertheless remains confronted at the limits of the pregiven world with a non-appearing strangeness, with something alien that withdraws from this framework of the world as a whole. In our opinion, however, what such confrontation with something beyond the world points to is the margin of the world as a whole rather than a cosmos that sets everything in order, a cosmos that the world as a whole only mirrors subjectively-relatively on any given occasion-an ordering cosmos that now shines through the world as a whole and encompasses the latter without residue, for with the construction of such an ordering cosmos, the strangeness of the external would merely be reduced to a new, now speculatively conceived and constructed correlation.

1 Written within the framework of the research project "Eugen Fink and French Phenomenology" (GAP 21-23337J). Some parts of the text are based on Novotný 2021, 95-112. I would like to offer my cordial thanks to Elizabeth A. Behnke for the translation of this text from the German.

2 However, Patočka was also originally inspired by Henri Bergson; see especially his 1931 dissertation, but also other early projects. Patočka, Přirozený svět: Texty z let 1931-1949, in Sebrané spisy 6: Fenomenologické spisy I (Prague: OIKOYMENH, 2008), 13-125. See also Karel Novotný, "Life and the Natural World in the Early Work of Jan Patočka (1930-1945)," in Early Phenomenology and its Reception in Central and Eastern Europe, ed. P. Eldridge and W. Ptotka, (Dordrecht: Springer, 2020), 187-202. 3 Patočka explicitly recognizes this in two important passages-see Patočka, 0 zjevování: Nepublikované studie, fragmenty a poznámky z 50.-70. let in Sebrané spisy 8/2: Fenomenologické spisy III/1. (Prague: OIKOYMENH, 2016), 717; Patočka, Body, Community, Language, trans. Erazim Kohák (Chicago and La Salle: Open Court, 1998 [1995]), 52; and also Patočka, Carnets philosophiques, trans. Erika Abrams (Paris: Vrin 2021), passim.

${ }^{4}$ Here I am thinking of D. Duicu, O. Stanciu, E. San, and C. Rocca; and, in France, M. Bernard, E. Tardivel, and F. Jacquet.

${ }^{5}$ In ten sections covering forty pages, Patočka outlines the prehistory and history of the natural world from Descartes to Heidegger; see Jan Patočka, The Natural World as a Philosophical Problem, trans. Erika Abrams (Evanston: Northwestern University Press, 2016), 98-160. Patočka speaks about Fink at the end of the eleventh section, 
which summarizes the second part of the work, Patočka, The Natural World as a Philosophical Problem, 158-60. Besides the essay "The World as a Whole and the Human World," this is the only published passage in which Patočka refers to a cosmological account-an account he himself does not subscribe to, as is unequivocally clear from the context. See Patočka, "The World as a Whole and the Human World," [1972] in: Die Bewegung der menschlichen Existenz. Phänomenologische Schriften II (Stuttgart: Klett-Cotta 1991), 257-64.

6 Patočka, The Natural World as a Philosophical Problem, 158.

${ }^{7}$ Patočka, The Natural World as a Philosophical Problem, 159.

8 Patočka, The Natural World as a Philosophical Problem, 160.

${ }^{9}$ See, e.g., the letter to Václav Richter of January 10-11, 1970 or the letter to Irena Krońska of November 18, 1969-or those of March 4 or September 30, 1970. For the first reference see Patočka, Dopisy Václavu Richterovi. (Prague: OIKOYMENH, 2001), 201-2.

${ }^{10}$ Here Patočka is relating his own account for the first time in his published writings. Nevertheless, he had already referred to it in a lecture given in 1968, shortly before this text was written; in the manuscript of the lecture, see the note on "Fink: 'double appearing': 1) the objective, real-the ancient: things arising from chaos, individuation from a prior whole [;] 2) the subjective, conscious-the modern: things are represented, illuminated by our mind." Patočka, O zjevování, 249. For the the reference to the lecture itself see Patočka, Body, Community, Language, 118.

${ }^{11}$ Patočka, The Natural World as a Philosophical Problem, 159-60.

12 In the lecture manuscript cited in the preceding note (n. 7), one can read the following explicit statement immediately after the passage on the "double appearing" in Fink: "In contrast, our manner of separation includes a reference to everything at each moment. We delimit ourselves not from individual things, but from the way in which the universe looks to us at the current moment, how we 'find ourselves' in it. Our movement-our individuation, our life-is thus a movement in relation to being, which mediates our relation with individual items in the universe and with the universe as a whole [. . . ]. Human beings become human beings the moment this understanding of the whole opens up for them, simultaneously with this. Human beings come into being as soon as the world comes into contact with them and becomes accessible to them." Patočka, O zjevování, 250.

${ }^{13}$ It is under this title-appartenance-that in his most recent book Renaud Barbaras is concerned with the same issue of the status of the lived/physical body that we are alluding to here. See Barbaras, Appartenance: Vers une cosmologie phénoménologique. (Leuven: Peeters, 2019). Cf. Novotný, Welt und Leib. Zu einigen 
Grundmotiven der Phänomenologie. (Würzburg: Königshausen \& Neumann 2021), 3848.

14 The external requirement for the publisher to justify reissuing the habilitation by providing it with an afterword became for Patočka an occasion to formulate his new position, which he was still trying to shape.

15 Patočka, The Natural World as a Philosophical Problem, 160.

16 Patočka, The Natural World as a Philosophical Problem, 160-61.

17 Patočka, The Natural World as a Philosophical Problem, 161.

18 The role of Aristotle has rightfully been emphasized not only by Barbaras in his cosmological works, but also by his students, whom he deeply influenced in this regard, some providing detailed commentaries (see especially Marion Bernad, Dragos Duicu, Ovidiu Stanciu, among others). Filip Karfík, Pierre Rodrigo, James Mensch, and Martin Ritter have devoted serious attention to Patočka's understanding of movement. Unfortunately, here we cannot address the extensive secondary literature on these topics. Here are just some of the main references: Marion Bernard, Patočka et l'unité polémique du monde (Leuven: Peeters, 2016); Dragos Duicu, Phénoménologie du mouvement: Patočka et l'héritage de la physique aristotélicienne (Paris: Hermann, 2014); Filip Karfík, Unendlichwerden durch die Endlichkeit. Eine Lektüre der Philosophie Jan Patočkas (Würzburg: Königshausen \& Neumann, 2008); Filip Karfík, "Mouvement, temps, espace dans l'Aristote de Jan Patočka," Patočka lecteur d'Aristote: Phénoménologie, ontologie, cosmologie, ed. C. V. Spaak and O. Stanciu (Paris: Éditions du Cercle Herméneutique, 2015), 195-212; James Mensch, Patočka's Asubjective Phenomenology: Toward a New Concept of Human Rights (Würzburg: Königshausen \& Neumann, 2016); James Mensch, Selfhood and Appearing: The Intertwining (Boston: Brill, 2018); James Mensch, Decisions and Transformations: The Phenomenology of Embodiment (Stuttgart: Ibidem Verlag, 2020); Martin Ritter, Into the World: The Movement of Patočka's Phenomenology (Dordrecht: Springer, 2019); Pierre Rodrigo, L'intentionnalité créatrice: Problèmes de phénoménologie et d'esthétique (Paris: Vrin, 2009); Pierre Rodrigo, "Symphysis: Patočka face à "l'empirie trop grossière et naïve" d'Aristote," 107-124; Pierre Rodrigo, PostPhénoménologies: Merleau-Ponty, Patočka, Barbaras (Leuven: Peeters, 2021); Ovidiu Stanciu, "Vers une pensé du "monde lui-même": Eugen Fink et les perspectives d'une philosophie cosmologique," Revue Philosophique de Louvain 114 (2016): 655-82.

${ }^{19}$ See Fink, Zur ontologischen Frühgeschichte von Raum - Zeit - Bewegung (Den Haag: Martinus Nijhoff, 1957); Fink, Sein, Wahrheit, Welt. Vor-Fragen zum Problem des Phänomen-Begriffs (Den Haag: Martinus Nijhoff, 1958); Fink, Alles und Nichts. Ein Umweg zur Philosophie (Den Haag: Martinus Nijhoff, 1959); Fink, Spiel als Weltsymbol 
(Stuttgart: Kohlhammer, 1960). Patočka explicitly refers to these publications in his texts, including in his book on Aristotle; see Patočka, Aristote, ses devanciers, ses successeurs, trans. Erika Abrams (Paris: Vrin, 2011), 32, 111, 193; for Fink, Zur ontologischen Frühgeschichte von Raum - Zeit - Bewegung.

20 The most frequently cited passage reads: "The idea behind my historical considerations is as follows. The becoming, the movement, that lies at the origin of all our experiences is itself impossible without a deeper and more elementary becoming-one that is not movement that is experienced, movement in the world, but the becoming, the movement, of the world as such: ontological becoming." Letter of March 20, 1964 to Robert Campbell, in which Patočka is characterizing his book on Aristotle, which had just appeared. See J. Patočka: Correspondence avec Robert Campbell et les siens 1946-1977, ed. E. Abrams (Grenoble: Millon 2019), 149.

${ }^{21}$ Renaud Barbaras, “Double monde," Alter 17 (2019): 26-27.

22 Barbaras, Le mouvement de l'existence: Études sur la phénoménologie de Jan Patočka (Chatou: Éditions de la Transparence, 2007); and Barbaras, L'ouverture du monde: Lecture de Jan Patočka (Chatou: Éditions de la Transparence, 2011).

23 Barbaras, "Double monde," and Barbaras, "Le refoulement de la vie," La phénoménologie et la vie, ed. Y. Ch. Zarka and A. Zafrani (Paris: Cerf, 2019): 201-19. 24 Patočka, Vom Erscheinen als solchem, 247.

25 Patočka, O zjevování, 243.

${ }^{26}$ Barbaras, “Double monde," 25-27; Barbaras, “Le refoulement de la vie," 201-2.

27 The lived/physical body would basically be "nothing but another name for this belonging-to." Barbaras, “Le refoulement de la vie," 209.

${ }^{28}$ For texts on the project of an "asubjective" phenomenology of the world as a whole, see Patočka, Die Bewegung der menschlichen Existenz, 267-452; Patočka, Vom Erscheinen als solchem. Texte aus dem Nachlaß, ed. H. Blaschek-Hahn and K. Novotný, (Freiburg/München: Alber, 2000), passim; cf. Novotný, Welt und Leib, 5176.

29 Patočka, The Natural World as a Philosophical Problem, 161.

${ }^{30}$ Fink's reading of Kant is in accord with this, and is correspondingly emphasized in his own notion of the cosmological difference: there can be no experience of the cosmos; it can only, and must only, be thought; cf., e.g., Fink, Alles und Nichts, 98.

${ }^{31}$ Letter of April 1972 to Irena Krońska, cited by Erika Abrams in her “Translator's Note," Patočka, The Natural World as a Philosophical Problem, 270-71.

32 Fink, Sein, Wahrheit, Welt, 64, 100-35, passim.

33 Patočka, O zjevování, 630-35.

${ }^{34}$ Barbaras, La dynamique de la manifestation (Paris: Vrin, 2013), 160. 
35 Rodrigo, Post-Phénoménologies: Merleau-Ponty, Patočka, Barbaras, (Leuven: Peeters, 2021), 196-97.

${ }^{36}$ Rodrigo, Post-Phénoménologies, 20.

${ }^{37}$ Patočka, Vom Erscheinen als solchem, 162-63.

${ }^{38}$ See also Novotný, Welt und Leib, 51-77.

${ }^{39}$ As he writes, for example, toward the end of his most recent book, "Thus the classic phenomenological figure of 'appearing-to' is surpassed in a new logical figure, that of 'appearing without a subject,' where Merleau-Ponty's figure of an anonymous appearing and Patočka's figure of asubjective manifestation are radicalized." Rodrigo, Post-Phénoménologies, 190.

${ }^{40}$ See the letter of April 4, 1974 to Ludwig Landgrebe.

${ }^{41}$ Rodrigo, Post-Phénoménologies, 165.

42 Barbaras, Appartenance, 51.

${ }^{43}$ Barbaras, Appartenance, 72.

${ }^{44}$ Rodrigo, Post-Phénoménologies, 199.

${ }^{45}$ Cf. "The World as a Whole and the Human World," in Patočka, Die Bewegung der menschlichen Existenz, 261: "a world without centers-an entirely non-centered world-is possible, thinkable [. . . ]. And yet in fact, there is a reference of appearingto-me to the world and the world-ground, a reference developed down to the final detail." Rodrigo too is seeking this fully developed reference as the "logic of appearing" when he writes of the gearing-in of appearing and being in and through movement.

${ }^{46}$ Rodrigo, Post-Phénoménologies, 20.

${ }^{47}$ Patočka, O zjevování, 630.

48 See Novotný, "Welt und Natur in der frühen Phänomenologie von Jan Patočka," Phänomenologie und Ökologie, ed. H. R. Sepp (Würzburg: Königshausen \& Neumann, 2019), 47-60; Novotný, Welt und Leib, 122-31.

49 Patočka, O zjevování, 631.

50 Patočka, O zjevování, 641.

51 Patočka, The Natural World as a Philosophical Problem, 161.

52 What is at stake here is the life of the inner, which is an important motif in Patočka's early work. See Martin Ritter, Into the World: The Movement of Patočka's Phenomenology (Dordrecht: Springer, 2019), 22-40, and the references above in the note 46.

53 Patočka, The Natural World as a Philosophical Problem, 165.

54 Patočka, Die Bewegung der menschlichen Existenz, 135, emphasis modified-K. N.

55 Patočka, Die Bewegung der menschlichen Existenz, 135. 
56 Patočka, Die Bewegung der menschlichen Existenz, 135.

${ }^{57}$ Fink, Spiel als Weltsymbol, 89.

${ }^{58}$ See Novotný, La genèse d'une hérésie: Monde, corps et histoire dans la pensée de Jan Patočka (Paris: Vrin, 2012), 51-78. 